\section{Commentary: Lung transplant: A humbling field where it never hurts to get lucky}

\author{
Jacob A. Klapper, MD
}

Humility is a very laudable human attribute. An individual's possession of it can be fleeting, especially when humility meets its most natural enemy: Success. Many times, success can breed overconfidence, self-aggrandizement, or boorish behavior. If you ever wondered what this looks like, I point you toward Michael Jordan's 10-part love letter to himself that debuted last summer on the sports network ESPN. Great basketball player. Zero humility.

An unfortunate reality of lung transplant is just how humbling it can be. Maintaining humility despite success is particularly advisable, especially because so much can and will go wrong. Take, for example, the case report in question. An uneventful lung transplant that proceeds in the standard course with nary a problem intraoperatively...until the end. Then, of all things, a membranous injury of the trachea is discovered. The authors handle this atypical situation with early extubation and, when the course was further complicated by acute graft dysfunction, by applying venovenous extracorporeal membrane oxygenation (VV ECMO). This decision was particularly critical because it allowed the surgeons to again extubate the patient and diminish the influence of positive pressure on the injury. ${ }^{1}$

Another word here on VV ECMO for airway complications. This was of course a freak injury, but a more common complication is early airway dehiscence. In that situation, stents can be utilized but even then sometimes flap coverage is necessary. Recently, at our own institution, stenting was performed in conjunction with an omental pedicle to reinforce the anastomosis and provide a tissue scaffold. To

From the Division of Cardiothoracic Surgery, Duke University Medical Center, Durham, NC.

Disclosures: The author reported no conflicts of interest.

The Journal policy requires editors and reviewers to disclose conflicts of interest and to decline handling or reviewing manuscripts for which they may have a conflict of interest. The editors and reviewers of this article have no conflicts of interest.

Received for publication Nov 24, 2020; revisions received Nov 24, 2020; accepted for publication Nov 26, 2020; available ahead of print Dec 8, 2020.

Address for reprints: Jacob A. Klapper, MD, Division of Cardiothoracic Surgery, Duke University Medical Center, DUMC 3954, Durham, NC 27710 (E-mail:

Jacob.klapper@duke.edu).

JTCVS Techniques 2021;5:106

2666-2507

Published by Elsevier Inc. on behalf of The American Association for Thoracic Surgery. This is an open access article under the CC BY-NC-ND license (http:// creativecommons.org/licenses/by-nc-nd/4.0/).

https://doi.org/10.1016/j.xjtc.2020.11.030

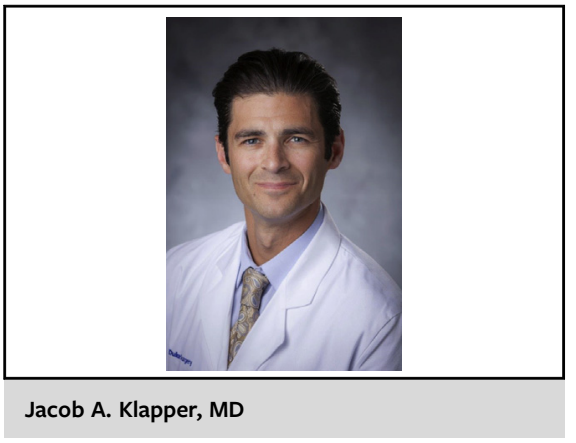

CENTRAL MESSAGE

A freak airway injury despite an uneventful transplant that was well managed with VV ECMO. Lung transplant is endlessly humbling and sometimes you need catch a little bit of luck.

facilitate this process, and diminish the need for positive airway pressure, we then employed VV ECMO. As with the case report in question, the airway healed nicely.

This story has a happy ending, and as many of us know, inexplicable complications such as this rarely result in: "Nearly 7 months from the [bilateral lung transplant], she continues to do well." It must also be said that besides maintaining one's humility, one must also hope for good luck when it comes to lung transplant. Of course, strong clinical judgment, and operative technique are important but in this field sometimes you just need to get lucky. And these authors did. I trust they possess the humility to recognize that.

\section{Reference}

1. Hwalek AE, Whitson BA, D'Souza D, Keller BC, Bhandary SP, Ganapathi AM Postoperative management of iatrogenic membranous tracheobronchial injury following bilateral lung transplant. J Thorac Cardiovasc Surg Tech. 2021;5:103-5. 